\title{
Integrated Impact of Climate Change and Socioeconomic Development on the Evolution of Camel Farming Systems
}

\author{
Bernard Faye $^{1^{\star}}$, Mahmadou Chaibou ${ }^{2}$ and Gilles Vias ${ }^{3}$ \\ ${ }^{1}$ CIRAD-ES, Campus international de Baillarguet, TA C/Dir B, 34398 Montpellier \\ cedex, France. \\ ${ }^{2}$ Faculté d'Agronomie, Université Abdou Moumouni, BP 10960, Niamey, \\ Niger. \\ ${ }^{3}$ VSF-Belgique, Bureau de la Coordination Régionale de l'Afrique de l'Ouest, BP 12632, \\ Niamey, Niger.
}

Authors' contributions

This work was carried out in collaboration between all authors. BF designed the study, performed the statistical analysis, and wrote the first draft of the manuscript. MC and GV

managed the literature searches and all data available in different institutions regarding camel demography and climatic changes in Niger. All authors read and approved the final

manuscript.

Research Article

Received $8^{\text {th }}$ May, 2012

Accepted $15^{\text {th }}$ September, 2012

Published $6^{\text {th }}$ October 2012

\section{ABSTRACT}

In Sub-Saharan countries, climate change has already been observed for several decades and is characterized by the decrease in mean rainfall with extensive periods of drought followed by short but severe rains. The dromedary camel, adapted to arid lands and low nutritive natural resources, follows the aridification of ecosystems as she/he did so when moving into Africa through the Sinai Peninsula at the beginning of the Christian era. Thus, the on-going desertification in Northern Africa increases the camel distribution area, both geographically and socially, e.g. with regard to its use by people who are not traditionally camel keepers. Elsewhere, camels are used differently, i.e. for their products (milk, agricultural work) rather than for their traditional uses (packing or riding). On the other hand, facing more contrasted crop ecosystems and an unbalanced climate, which seem to contribute to emerging diseases with complex and often unknown aetiologies, caused high unexplained deaths. These global trends would trigger more changes of 
camel farming systems in Sahelian countries if climate change intensifies continuously in the next decades.

Keywords: Camel; Sahel; camel demography; emerging diseases; drought; climate change.

\section{INTRODUCTION}

In the past, the scientific literature stressed the ability of the camel to survive in desert ecosystems and underline physiological particularities testifying its adaptation to arid conditions (Yagil, 1985; Wilson, 1989; Bengoumi and Faye, 2002). It is no noticeable that the camel belongs to domestic species characterized by a hyper-adaptation to a given milieu leading to low plasticity (like the yak, reindeer or lama), but most of their rural activities are kept in remote areas (Richard et al., 1985a; Faye, 1997). The indirect effects of climate change on animals were described by authors pointing out their impact on feed resources (including water) and diseases (Alkolibi, 2002; Lioubimtseva and Henebry, 2009; Sirohi and Michaelowa, 2007). Well adapted to drought and widespread resources, the question of its adaptation to climatic changes (Godard, 2010) is one of the main interests of the camel scientists' community (Faye and Bonnet, 2012).

In Sahelian countries, weather reports over one century show that climate change is oftentimes characterized by more severe droughts than in the past and (especially in recent time) by very abundant rainfall in a shorter time period. These changes have effects on camel stocks and breeding and on their geographical distribution, health status and social use by the farmers. In the present paper, the impact of climate change on camel farming systems is illustrated in terms of the camel stocks and breeding, geographical distribution and disease in a case study at Niger.

\section{CURRENT SITUATION OF THE CAMEL POPULATION WORLDWIDE}

The camel population has been increasing regularly since 1961. Yet present estimation of world camel population by FAO $(24,823,000$ in 2009) is smaller than the sum of individual national estimations $(27,083,000)$. In 2009 , the camel population was mainly concentrated in the Horn of Africa and in Sahelian countries. Somalia, Sudan, Ethiopia, Kenya, Djibouti and Eritrea had $58 \%$ of the total camel population in the world. The camel population in 2009 was slightly more than double than that of 1961 , corresponding to an annual growth of $2.1 \%$. Compared to the annual growth of other species worldwide, the camel population has been growing faster than that of cattle, sheep, horse and lama, somewhat similarly to that of buffalo, but slower than that of goat (Table 1).

However, the annual growth is very variable from one country to another (from $-2.1 \%$ in the former Soviet republics to $13 \%$ in Somalia). Overall, the pattern of annual growth in the last 48 years helps to identify five types of countries: 1) Countries with a steadily growing camel population, mainly based in the Horn of Africa and Near East, 2) Countries with a recent but important growth of their camel population, mainly in Western Africa and the Arabian Peninsula, 3) Countries with a stable camel population (Kuwait, Lebanon, Libya and Senegal), 4) Countries with a steadily declining camel population (mainly in Central Asia, China and India), and 5) Countries with a severely declining camel population (Iraq, Turkey, Morocco - not including Western Sahara). 
Table 1. Livestock population growth between 1961 and 2009 (index 100 in 1961) (source: FAOstat, 2009)

\begin{tabular}{lll}
\hline Species & $\mathbf{1 9 6 1}$ & $\mathbf{2 0 0 9}$ \\
\hline buffalo & 100 & 212.8 \\
cattle & 100 & 146.5 \\
goat & 100 & 252.3 \\
horse & 100 & 95.0 \\
lama & 100 & 148.1 \\
sheep & 100 & 108.3 \\
camel & $\mathbf{1 0 0}$ & $\mathbf{2 0 4 . 3}$ \\
\hline
\end{tabular}

Negative or slow growth has been observed in Asia and Northern Africa (less than $2 \%$ per year), regular growth in Africa (2 to $5 \%$ ) and high growth (more than $5 \%$ ) especially in Western Africa and the Arabian Peninsula (Fig. 1). The decline in Asia is linked to the regular decline of the Bactrian camel population, mainly in Mongolia and China. In Mongolia, recent exceptional climatic events known as dzud (very cold winter with large quantities of snow) caused a high mortality in the camel population (Begzuren et al., 2004).

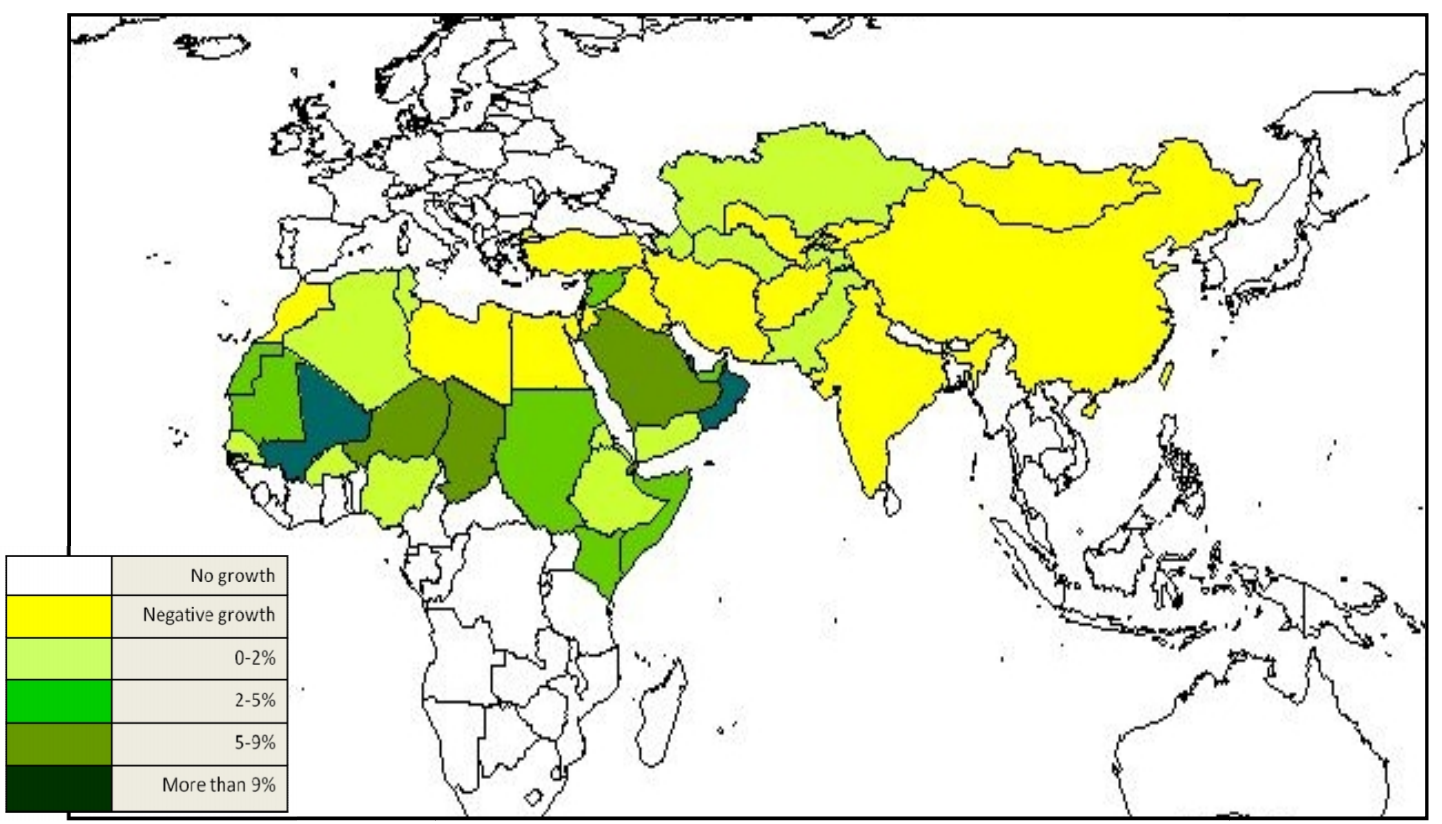

Fig. 1. Camel population growth in the world between 1961 and 2009 (in \% per year) (Source: Faye and Bonnet, 2012)

The decline of the camel population is not correlated to the development level of the country. There is no correlation between the camel population growth and the GDP/capita (Fig. 2). The recent growth observed in Sahelian countries could be linked to: 1) a highest change in camels after the droughts that affected these countries and 2) an adjustment of national statistics after a census (for example in Ethiopia, the camel population was estimated at 1,070,000 head in 1992 and 1,983,000 head in 1993 in spite of the Eritrean secession). Similar figures were observed in Kenya where the camel population was estimated at 1.1 
million head in 2009 according to FAO statistics, but reached 1.9 million in the 2010 census (Ngeiywa, 2012).

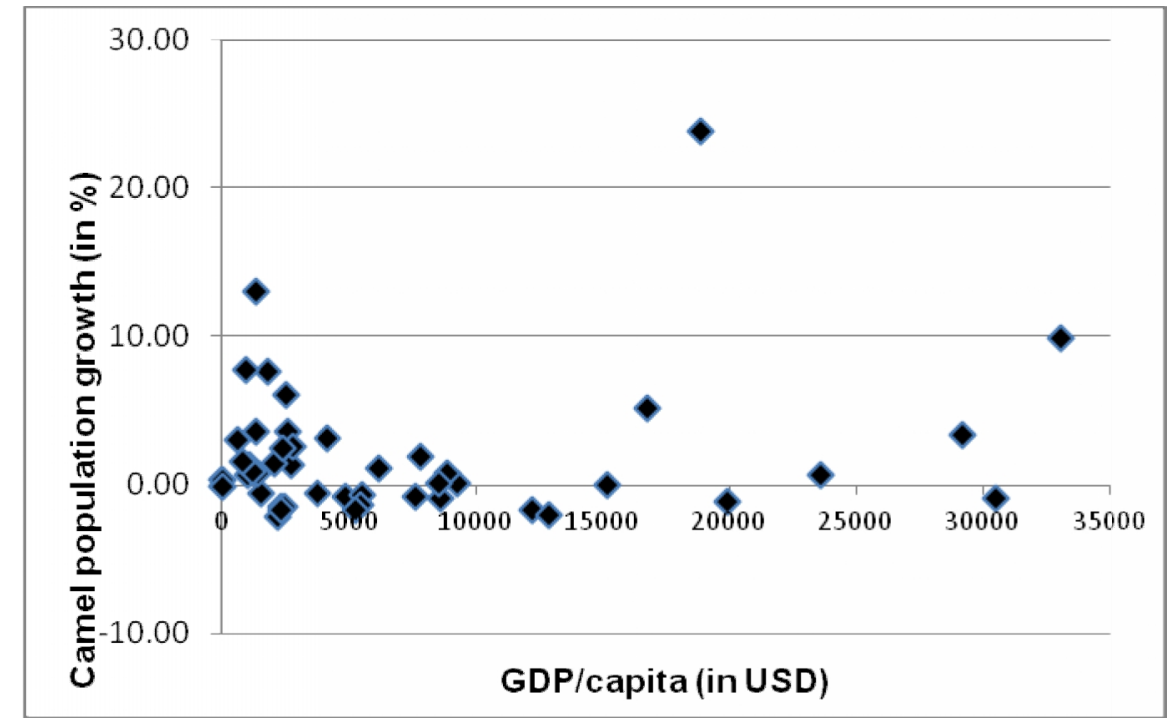

Fig. 2. Relationships between camel population growth and GDP/capita in 2009 (Sources: FAOstat, 2009 and UNDP report, 2009)

\section{CURRENT TRENDS OF THE SAHELIAN CLIMATE}

The Sahel has a long history of climate stress events (Tschakert, 2007) but for a century, the Sahelian climate has been characterized by marked drought periods resulting in devastating famines, particularly during the 1970s (Hulme, 2001) and causing the advance of desertification and degradation of the vegetation (Nicholson, 2001; Ahmedou et al., 2008).

Since year 1900 , Sahara has extended by $250 \mathrm{~km}$ to the regularly south and along a 6000 $\mathrm{km}$ front (Leroux, 2004). The rainfall deficit has been increasing since the 1970s (Fig. 3) although an increase in the water flow has been observed (Mahe and Paturel, 2009) and linked to less frequent but more abundant rainfall (Little et al., 2001).

The tendency to rainfall decrease is accompanied also by a decrease of the rainy season length: on average at Niamey, this decrease was 7 days over the period 1990-2009. The dry sequences during the rainy season increased especially in August leading to a degradation of the pastures before the end of the rainy season (Zika, 2012). At the same time, the analysis of the maximum temperatures shows that the tendency is associated with the rise (Zika, 2012). This increase in the maximum temperatures is estimated at $1^{\circ} \mathrm{C}$ over the period 1961-2010 (Fig. 4).

It was recorded also a decrease of low minimal temperatures (below the normal) from 1961 to 1968, then from 1974 to 1983. From 1990, a continuous increase in the minimal temperatures was observed (Fig. 5). Thus, the analysis of the historical data corroborates the results obtained by the perception of the population for which the temperatures increase in day as in night (Zika, 2012). For the future, according to the "Programme d'Action Nationale d'Adaptation aux changements climatiques" (PANA: National program of 
adaptation to climatic change in Niger, 2009), it is expected to observe an increase of temperature of $0.92^{\circ} \mathrm{C}$ in $2025,1.94^{\circ} \mathrm{C}$ in 2050 and $2.1^{\circ} \mathrm{C}$ in 2075 . The rainfall decrease is estimated to $1.5 \%$ in 2025, but a slight increase is expected in $2050(+0.6 \%)$ and 2075 $(+0.8 \%)$.

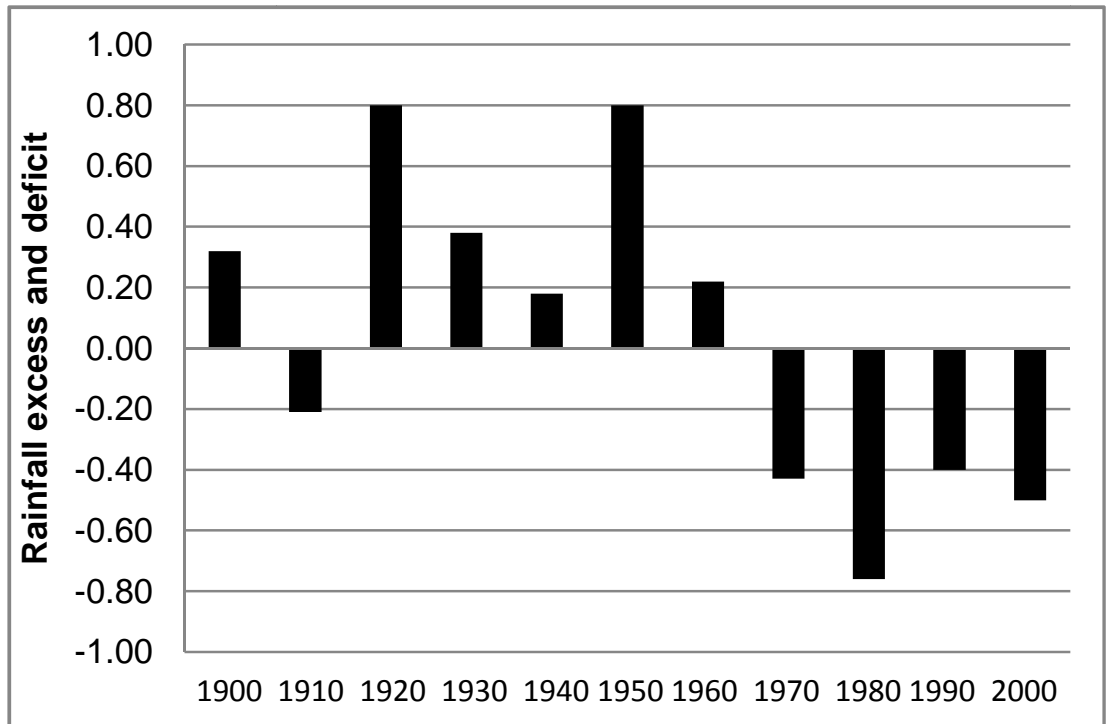

Fig. 3. Decennial trends of rainfall excess and deficit in the Sahelian area since 1900 (adapted from Ozer and Erpicum, 1995 and Zika, 2012)

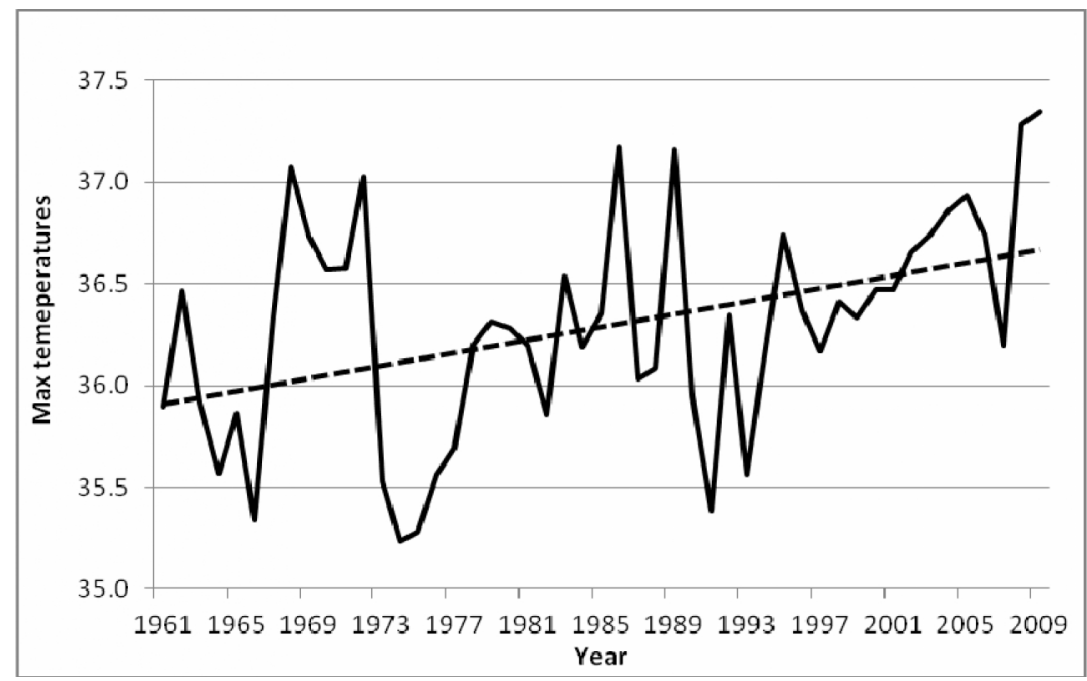

Fig. 4. Changes and linear trend of the maximal temperatures over the period 19612009 at Niamey, Niger

(Source: Zika, 2012)

These trends have observable impacts on livestock management, rangelands and animal health (Thornton et al., 2009), such as: 
- Risks on the nutritive value of available feed resources and on biomass availability (Herrmann et al., 2005).

- Increased risks of conflicts between pastoralists and farmers (Thebaud and Batterbury, 2001).

- Developing trends of mixed crop-livestock systems (Mortimer and Adams, 2001).

- Increased emerging epidemiological risks linked to vectors spreading widely after abundant rains (Colwell et al., 2011).

- Increased in parasitological risks linked to water flow excess (Wall et al., 2011).

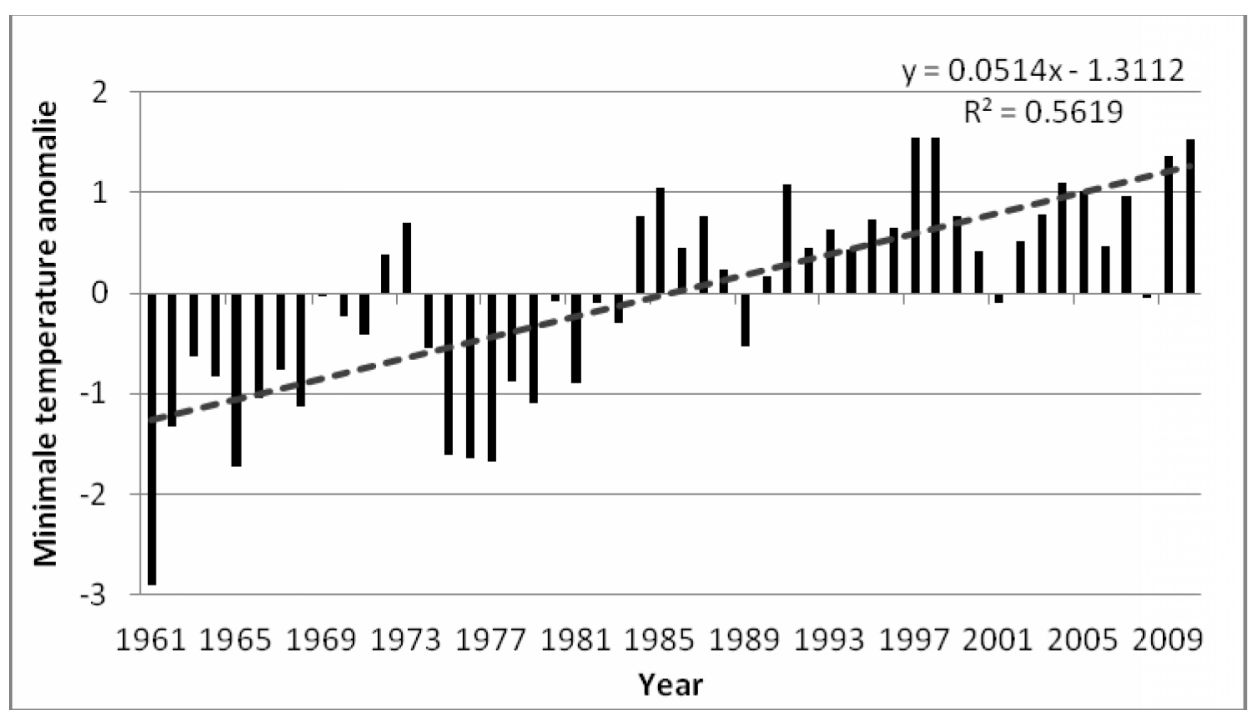

Fig. 5. Anomalies of the minimum temperatures and linear trend over the period 19612009 at Niamey, Niger

(Source: Zika, 2012)

Based on Clim Prospect model (Badolo et al., 2011), the different parameters of the agriculture field can be classified according to their sensitivity to the climatic risk (Table 2). According to this estimation, the camel appears among the less sensitive animal. However, camel farming has undergone changes such as: 1) the expansion of the geographical distribution of the species, 2) the use of the camel with its higher integration in mixed croplivestock systems and 3) the increased risk to emerging diseases.

\section{EXPANSION OF THE CAMEL DISTRIBUTION AREA}

In the past thirty years, the expansion of the camel distribution area has been clearly observed in sub-Saharan countries. The "desert belt" of Sahara corresponded roughly to the location of camel farming. Today, the expansion of the camel is still intimately linked to the desertification process. Since the camel arrived on the African continent, the expansion of camel herds was concomitant with the desertification of Sahara (Epstein, 1971), probably at the beginning of the Christian era. The presence of camels in Sahara progressively extended to reach its height in the $16^{\text {th }}$ century (Wilson, 1984). Afterwards, the distribution area of camels could be considered more or less stable, but a new trend has been observed since the 1970s. 
Table 2. Matrix of sensitivity to climatic risks (from Badolo et al., 2011)

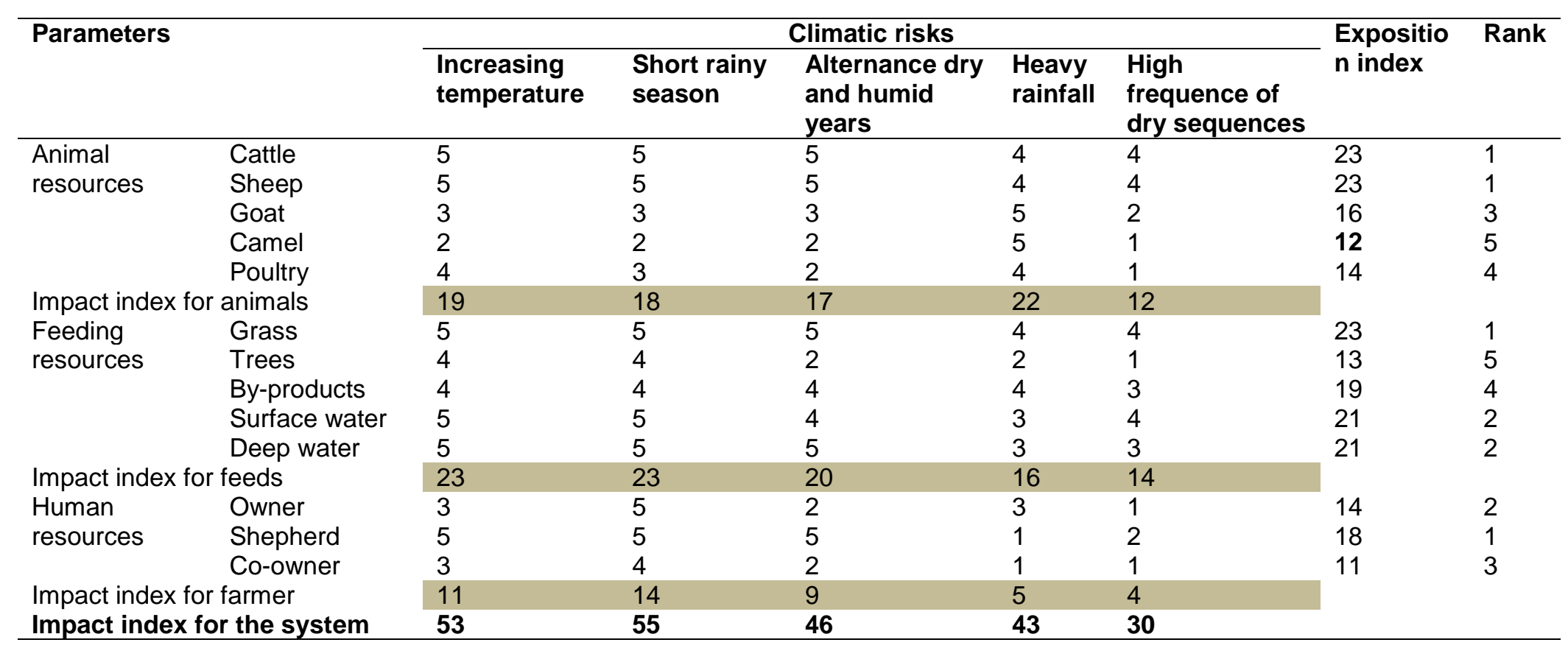


Nowadays, camel farms are significantly present in the north of Nigeria, Cameroon, the Central African Republic (RCA), the north of Uganda and even Tanzania (Swai et al., 2011). For example, in Chad, camel herds usually reared under long transhumance patterns go today up to the RCA border or even beyond (Marty et al., 2009). In Kenya, the camel population has invaded a wide part of the country, even areas inhabited by Massaï, who are traditionally cattle breeders (Cecchi et al., 2010). In Ethiopia, the expansion of the camel population has also been associated with a change in the altitude limit at which the camel was usually observed, passing from $1,500 \mathrm{~m}$ in the 1980 s up to $2,000 \mathrm{~m}$ today (personal observation).

In Niger, the presence of camels in southern areas where crop farming prevails (sorghum, millet, maize) significantly increased. In the agricultural regions of Tahoua, Maradi, Zinder, the camel population significantly increased. This increase is observed in pastoral zones, but also in periurban areas, around secondary towns such as Tanout or Agadez.

According to the "2007 general census on livestock and agriculture" (RGC/A, 2007), the camel population in Niger was two-fold bigger in 2006 (1.5 million heads) than in 1988 $(800,000$ head), i.e. in less than 20 years. The rate of settled herds among the camel population is low in Sahelian departments (3.1\% in Diffa, $4.9 \%$ in Maradi), but increases around big Saharan cities (10.2\% in Agadez, $10.8 \%$ in Tahoua, $25.7 \%$ in Zinder) and becomes preponderant in the southern departments $(6.8 \%$ in Filingué, $72.0 \%$ in Dosso and $100 \%$ in Niamey). In other words, the expansion of camels is linked to the increasing of their sedentarisation. The current expansion is also linked to a partial but progressive transfer to ethnic groups with a more sedentary life and no camel breeding tradition (Djerma, Haoussa) at the expense of other groups practicing traditional camel farming (Tuareg, Arab, Toubou).

Indeed many were dispossessed of their livestock during the severe droughts of the 1970s and 1980s, which contributed to the transfer of livestock ownership to settled populations (Thébaud, 1988). They might also have initiated their slow migration to the south at the time when camel capitalization by peasants and agropastoralists began. Camel expansion is also reflected in their acceptance by Wodaâbe pastoralists who are usually deeply attached to cattle breeding (Faye, 2006; Kratli, 2007). For them, camels represent a security tool for their livestock systems during hard times. These transfers from one species to another according to climate risks are widely observed in the entire Sahelian belt, and mainly concern small ruminants or dromedaries as is the case in Somalia (Bonnet and Faye, 2000). In other words, the expansion of camel distribution appears as much related to a human expansion (occupation of new spaces by camel breeders with a tendency to convert to agricultural activities) as to an expansion of the species itself. The camel consequently tends to occupy spaces where the groups of settled agropastoralists are predominant. These farmers adopt camels for agricultural activities, in spite of the shift of the lowest isohyets to the south (Fig. 6).

Comparison of censuses (1984 and 2006) reveals the demographic and territorial dynamics of the camel population by zone since 1984 (Richard et al., 1985b), during the livestock project in Center-East Niger (PENCE) (Fig. 7). The main camel population increase was observed in the southern departments of the country, with a very high increase in the three most southern departments (Diffa, Zinder and Maradi), in particular around the towns of Aguié, Guidam-Roumji and Birni-N' Konni. The percentage of camels compared to the biomass of domestic ruminants (BDR) is the ratio between the total weight of camels and that of the total sum of the weights of cattle, sheep and goats. This ratio doubled between 1984 and 2006, passing from 10.2 to $19.7 \%$ in Diffa department and from 9.7 to $18.4 \%$ in 
Maradi department. Only Zinder department registered a low growth with a BDR passing from 10.1 to $11.8 \%$, especially caused by a very high increase in small ruminants in the local livestock.

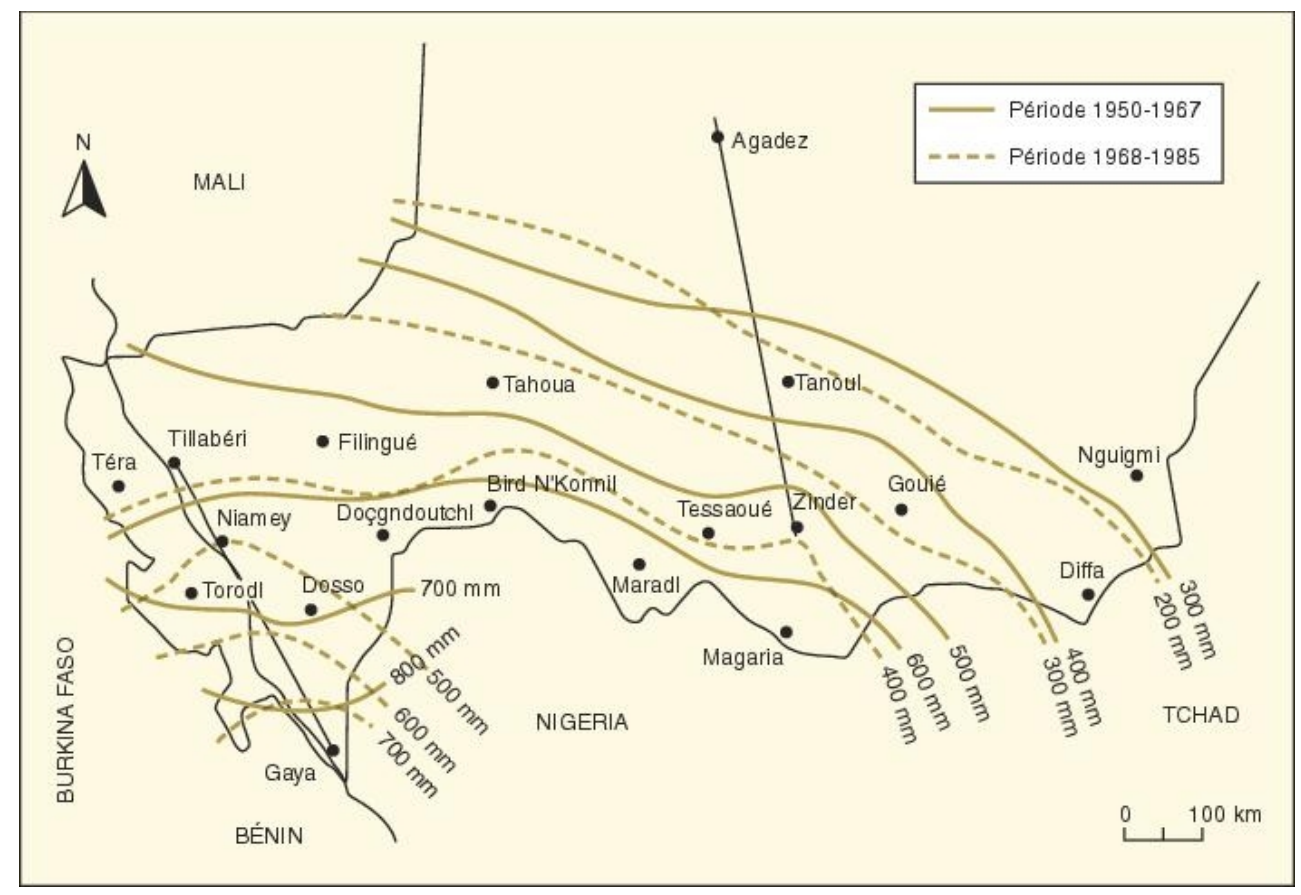

Fig. 6. Rainfall map in South-Niger: the isohyets are calculated from the mean humid years 1950-1967 (-) and dry ones 1968-1985 (- - - )(adapted from Ozer and Erpicum, 1995)

\section{CHANGES IN THE USE OF CAMELS}

Far away from the image of tradition widely associated with Sahelian society, the changes in the mode of land use as a result of interaction between governmental policy, rural and pastoral producers, urban stakeholders, international development agencies and other actors (Raynaut, 2001), contribute to the diversification of economical activities, even in the pastoral communities linked to their camels. Thus, the camel farming is going progressively out of the traditional practices (packing and riding). The main changes in the use of camels are four ways: 1) the camel population tends to increase in settled livestock farming systems, 2) camels tend to be used in agriculture-related works, 3) the camel commodity channel is more closely market integrated and 4) camel plays an increasing role in the security of farming systems traditionally focused on cattle breeding.

\subsection{A Still Slight Tendency Toward a Sedentary Mode of Breeding}

Many people believe that Tuaregs, the most famous desert pastoralists, keep their camels for riding or as pack animals, and use them for the caravan activity, which has however sharply declined, or for the transport of wood and fodder toward urban zones (Faye and Brey, 2005), i.e. the dromedary is regarded as the animal of the nomads. However, if the 
status of camel owners slightly tends to change, the increase in the camel population in settled populations appears remarkable and induces notable changes in the use of these animals. The rate of settled camel owners has apparently slightly increased in the last two decades, with high differences reported between regions. The percentage of dromedaries (i.e. individual animals and not herds) reared according to a sedentary mode in 2006 was $10.23 \%$ in Agadez, but only 3.13 and $4.94 \%$ in Diffa and Maradi, respectively. It reached $25.7 \%$ in Zinder, $65.85 \%$ in Dosso and $72.10 \%$ in Tillabery. Similar data were not available in the 1980s, but according to the surveys carried out within the framework of PENCE cited above, the percentage of camels reared according to a sedentary mode was approximately $5 \%$ on average in the departments of Diffa, Maradi and Zinder.
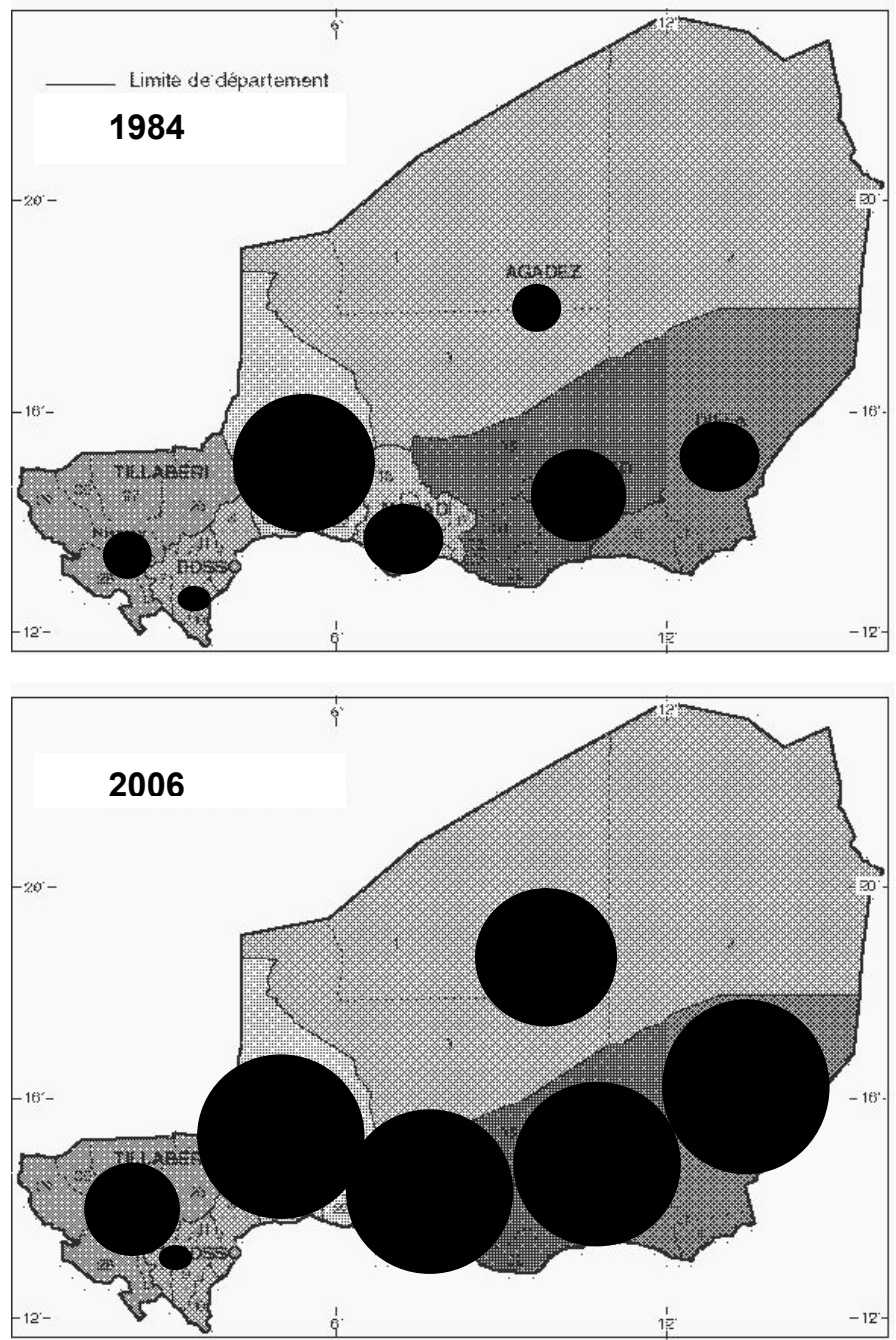

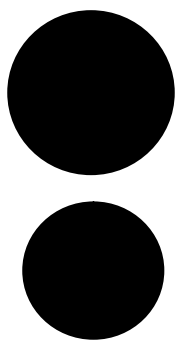

$>200000$ heads

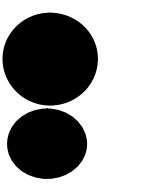

75-100000 heads

50-75000 heads

30-50000 heads

$<30000$ heads

Fig. 7. Camel population in the departments of Niger according to 1984 and 2006 censuses 
If the settlement process still seems low, on the contrary, the use of the dromedary for agricultural work (scarifying, ploughing, sowing and weeding) has developed considerably (Vias et al., 2004), including in periurban areas and even within cities where its role as carting animal for municipal services is widespread (Faye, 1999). New dynamics initiated in some farms in the south of Niger over a decade were related to the use of the dromedary for agricultural work. These new dynamics were justified by the comparative advantage of this species. Indeed, the dromedary is endowed with a power capacity higher than that of other domestic animals. It is more powerful, faster and more resistant than a pair of oxen (Vall, 1996).

Thus, the dromedary has been gradually integrated in the farms, where its power performances, its adaptation to long walks, its resistance to thirst and its sobriety have been put to use in agriculture and harnessed transport. It represents, from this point of view, the ultimate stage of agricultural intensification in semiarid zones. Little used in West Africa, camel draft power is however widespread in North Africa, Ethiopia and India (Faye, 1997). Its development in Niger is recent and based on advertizing campaigns through several livestock projects in the agricultural zone (Vias et al., 2004). Its use answers the quest for a development that is sustainable and adapted to the available resources of Niger.

\subsection{Market integration of camel products}

However, the market integration of camel products represents the most outstanding change in the last twenty years. This evolution does nothing but obey a general tendency on the area which under the effect of the urbanization, demographic growth and progress of the cash-crop agriculture, fits more and more in a globalized economy (Cour, 2001). Thus, regarding camel rearing, since export of live animals toward Algeria and Libya had probably been a common activity for a long time, the increase in camel meat demand on Maghreb markets stimulates mainly informal but efficient trade-circuits. The authorities from Niger even complained of the removal of too many young males for live export although this offered a commercial opportunity rather than present a risk of reducing the camel population which is in fact constantly increasing. Unfortunately, data on these animal transfers, volumes and values are lacking, contrary to cattle market (Turner and Williams, 2002).

The camel is also a dairy animal whose dairy vocation has been known for a long time, but camel dairy products have only recently integrated the market. In Agadez, the implementation of a mini-dairy plant has been maintained for many years in spite of difficulties related to milk collection among populations in constant mobility (Hammo et al., 2003). Tests to promote cheese making also took place in pastoralist milieu with mitigated success (Vias et al., 2003). These changes, however, testify an important cultural change since milk, traditionally used as a gift, becomes a commercial product, which enables nomads, who usually feel excluded from the economic development process, to integrate the market. These tendencies could induce, elsewhere and particularly in Mauritania, development dynamics in the camel milk sector under the influence of a primarily private initiative (Abdeirrahmane, 1997; Faye et al., 2003). A very varied range of dairy products would thus be proposed on the market (Mohammed, 2003).

In a more subdued way, the changes observed in Niger are emblematic of the dynamics operated by a certain intensification of camel farming. Today, this translates into an increased demand for feed supplementation for fattening or dairy production, and also for disease prevention and access to veterinary products. Around Agadez, a dairy basin was 
thus constituted (Chaïbou and Faye, 2005) in which settled some of the camel herds located around Agadez town (Fig. 8).

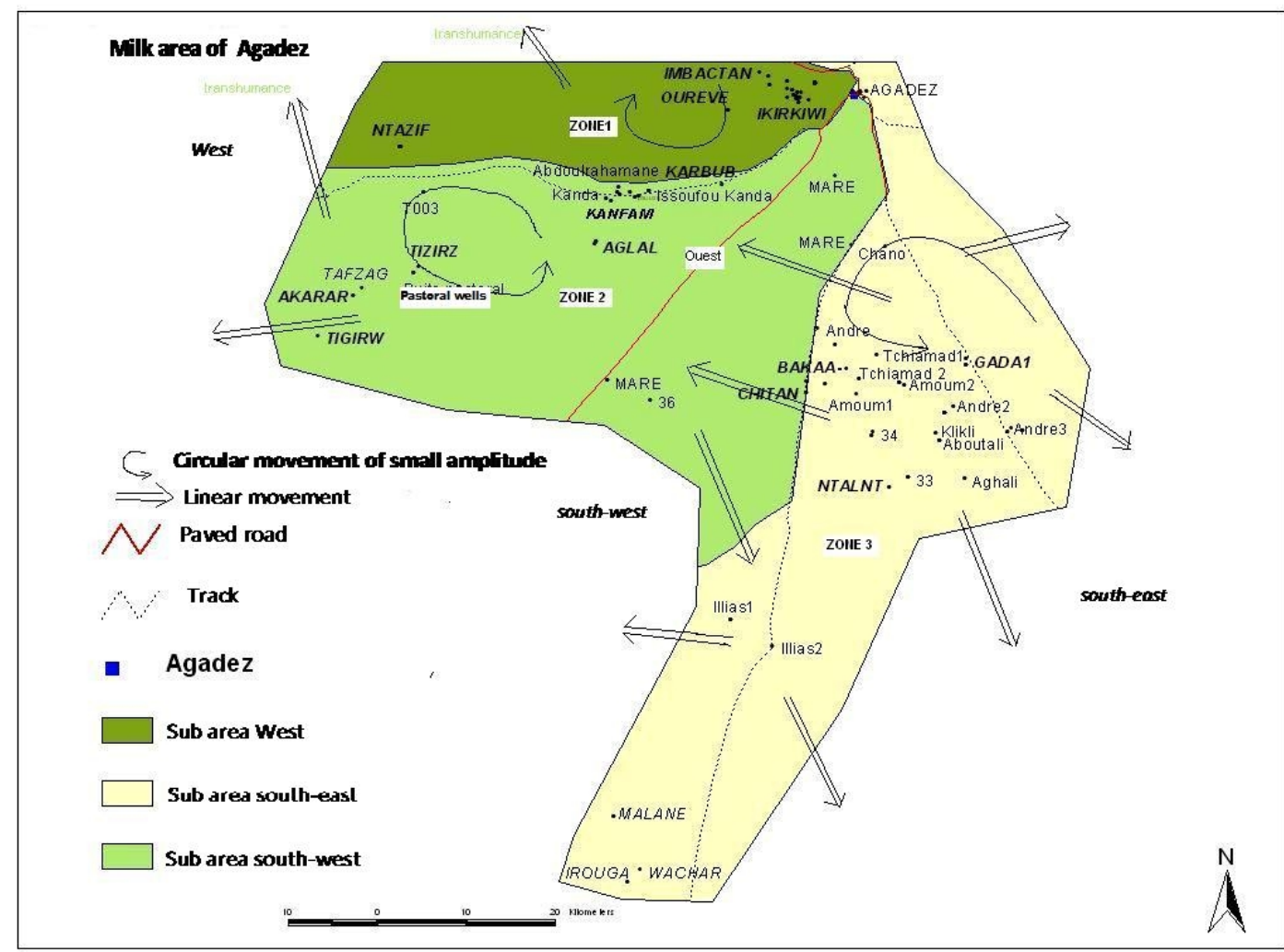

Fig. 8. Description of the milk basin around Agadez city based on the camel milk production with movements of the production units (adapted from Chaïbou, 2005)

\subsection{The camel, an element for the security of cattle farming systems}

In pastoral zones where uncertainty is a common fact among stockbreeders, security of production systems is essential. Traditionally, strategies for security concern three aspects (Thébaud, 1988): 1) mobility of the herds which results in a nomad or transhumant mode, 2) sharing the herd in social space by a complex system of loan ensuring a solidarity network which contributes to poverty alleviation (Potkanski, 1999; Faye, 2009) and 3) alleviation of climatic and medical risks by rearing multi-species herds. Thus, in most cases, camel stockbreeders have small ruminants, even cattle (Faye, 1992). In the investigation carried out within PENCE, $89.1 \%$ of the herds comprised several species, $59.4 \%$ included all the ruminants, $29.7 \%$ camels and small ruminants, $4.8 \%$ camels and cattle. The specific camel herds were rare with only $6.1 \%$ of the herds (Richard et al., 1985b). However, it could be the main species depending on the areas and ethnic groups, and their degree of specialization in camel rearing (e.g. Arab Kababish in Sudan, Sahraoui in Western Sahara, Somalis in the Horn of Africa, Raïka in India). 
As announced above, camel farming in the pastoral zones of Sahelian countries is in the hands of well identified ethnic groups. In Niger, Tuareg, Toubou and Arab are the populations specialized in this species (Pacholek et al., 2000) contrary to Peul who prefer cattle. However, a major trend has been observed with regard to the increased presence of dromedaries in the cattle herds of Peul Wodâabe stockbreeders following droughts for almost the last two decades. This trend is related to the concern for security of the production systems. These stockbreeders return to cattle breeding in the years with more clement climate (Kassahun et al., 2007). It is a strategy for security during arid periods and not for livestock restocking which is based on the high prolificacy of goats. On the contrary, the part of cattle was increased in Somalian herds in the 1970s, exposing the production systems to greater vulnerability during the severe droughts at the end of the $20^{\text {th }}$ century (Bonnet and Faye, 2000). After the heavy death toll among cattle, camelids were reintroduced into the herds.

\section{EMERGING DISEASES}

The impact of climate change on animal health could be summarized three ways: 1) direct effects caused by heat stress for example, leading to over-mortality, 2) indirect effects as a result of more favorable conditions for microbes to develop, parasites or vectors to pullulate, and 3) indirect effects on the adaptation mechanisms of animals facing resource and/or water shortage (Nardone et al., 2010; Wall et al., 2011). The high health constraints in camel farming are well known and have been listed for a long time under the main classical diseases such as trypanosomosis, mange, camelpox or gastro-intestinal parasitism (Curasson, 1947; Wernery and Gaaden, 2002). However, at least in the past decade, new cases marked by severe symptoms, high mortality and then impossibility to form a precise diagnosis have emerged in several Sahelian countries.

Thus, an epizooty prevailed in the Horn of Africa in 1995-1996, marked by febrile attacks, a highly contagious respiratory syndrome with a high morbidity (up to 90\%) and a mortality varying from 5 to $70 \%$ depending on the herd and treatment administered (Roger et al., 2000). The high prevalence of peste des petits ruminants (PPR) in the zone as well as symptoms similar to those of rinderpest suggested the presence of morbillivirus. Similar data were published in Sudan (Khalafalla et al., 2005) where several mortal epizooties have been reported in the early 2000 s, as well as in Kenya, without clearly identifying the causal agent although PPR virus was suspected. The pastoralists of these countries considered those diseases as new ones and attributed to them specific names, e.g. Firaanfir, Laaba or Yudleye (Khalafalla et al., 2010).

In 2003-2004, a large number of dead camels were also reported in Mali, Niger and Chad (personal communication). The symptoms were not specific and death occurred quickly. Some witnesses spoke about a "stunning death". No quantitative data was available because no exhaustive survey was carried out, but the death rates seemed very high. Anthrax was suspected for a moment as well as an acute form of trypanosomosis, but the results of laboratory analyses did not confirm them. It seemed that all the dead animals were heavily infested by ticks. These ectoparasites could find favorable conditions to their development under climate change (Olwoch et al., 2007). An investigation was carried out by the qualified services of Niger on animals coming from exposed areas. Hematologic analyses revealed a high number (76\%) of cases of anaplasmosis and babesiosis. Anaplasma and Babesia are blood parasites described until now as only causing subclinical diseases in the camel (i.e. without apparent symptoms). However, this assumption was not confirmed because of the lack of epidemiological information. The characteristic symptoms 
of blood parasitism (hemolytic anemia and hemoglobinuria) were not confirmed. Still in Niger, many cases of severe xerophthalmia associated with purulent or bilateral sinusitis causing eye loss were observed, without establishing the cause.

More recently in Somalia, Ethiopia and North Kenya, sudden deaths concerning hundreds of animals were reported and their assumed causes included plant intoxication, mineral deficiencies until the main viral diseases (PPR, blue-tongue, foot-and-mouth disease, Rift Valley fever) were suspected, but at time of writing they have not been confirmed.

Thus, the emergence of new diseases in this species, although famous for its resistance to them, occurred in many cases in the present decade. The causes of these diseases are not necessarily identical because the symptoms are not always the same. Multiple factors are also probably involved, and immuno-depressive elements, including certain viruses, can aggravate parasite infections. Unfortunately, investigations have been hindered by the difficult access to sick animals, often located in remote areas.

\section{CONCLUSIONS}

It would be hard to attribute all these changes in camel population dynamics only to the direct effect induced by climate change. Yet, the proper dynamic characteristics of pastoral societies face to the growing urban demand in animal protein, the pressure of the global economy also have an impact on the observed evolution, notably on the progressive market integration. Elsewhere, the emergence of new diseases in camel is as well linked to the climatic effect as to the changes in the management system of the camel farms with a trend to intensification of the production. But, the indirect effects induced by the pressure of climate change on spatial distribution of camel and, consequently, on the relationships between social, economic use, resource management, and interactions between environment and epizootiological risks, cannot be ignored. If the expansion of the dromedary in the past proceeded in relatively empty spaces, the current extension faces to more highly anthropized areas, increasing the interactions with human communities less accustomed to the species, and especially imposing modifications in the management of the farming systems. With this study, advanced in-depth analyses are needed to identify the possible evolutions of the camel population, and its geographical distribution, especially in Sahelian countries where the camel expansion appeared quite important. The knowledge of these evolutions is a mean to assess their sustainability and thus to facilitate decision-making for the camel farming development.

\section{COMPETING INTERESTS}

Authors have declared that no competing interests exist.

\section{REFERENCES}

Abeiderrahmane, N. (1997). Camel milk and modern industry. J Camel Pract Res, 4, 223228.

Ahmedou, O.C., Nagasawa, R., Osman, A.E., Hattori, K. (2008). Rainfall variability and vegetation dynamics in the Mauritanian Sahel. Clim Res, 38, 75-81.

Alkolibi, F.M. (2002). Possible effects of global warming on agriculture and water resources in Saudi Arabia: impacts and responses. Clim changes, 54, 225-245. 
Badolo, M., Yigo, L., Sidibe, A. (2011). Design of an intervention scheme for increasing the resilience of food security to climate risks in Burkina Faso. Working paper $n^{\circ} 1$, IAVS working papers, Burkina Faso, 9.

Begzsuren, S., Ojima, J.E., Coughenour, D.S., Chuluun, M.B. (2004). Livestock responses to droughts and severe winter weather in the Gobi Three Beauty National Park, Mongolia. J Arid Environ, 59, 785-796.

Bengoumi, M., Faye, B. (2002). Adaptation du dromadaire à la déshydratation. Sécheresse, 13, 121-129.

Bonnet, P., Faye, B. (2000). Enjeux zootechniques de la famine en Ogaden. Les Nouvelles d'Addis, n¹8. Aug. 2000, 15.

Cecchi, G.W., Shaw, W., Marletta, A., Mattioli, A., Robinson, T. (2010). Geographic distribution and environmental characterization of livestock production systems in Eastern Africa. Agric Ecosyst and Environ, 135(1-2), 98-110.

Chaïbou, M. (2005). Productivité zootechnique du désert : le cas du bassin laitier d'Agadez au Niger. Thèse en biologie intégrative, Université de Montpellier II (France).

Chaïbou, M., Faye, B. (2005). Fonctionnement des élevages camélins de la zone périurbaine d'Agadez au Niger. Enquête typologique. Rev Elev Méd Vét Pays Trop, 58(4), 273-283.

Colwell, D.D., Dantas-Torres, F., Otranto, D. (2011). Vector-borne parasitic zoonoses: Emerging scenarios and new perspectives. Vet. Parasitol., 182, 14-21.

Cour, J.M. (2001). The Sahel in West Africa: countries in transition to a full market economy. Global Environ. Change, 11, 31-47

Curasson, G. (1947). Le chameau et ses maladies. Vigot Frères (publ), Paris, 462.

Epstein, H. (1971). History and origin of the African camel. In: The origin of the domestic animals in Africa. New York, African Publishing Corporation, 558-564.

FAO. (2009). Food and Agricultural Organization, United Nations. Available at: http://faostat.fao.org/site/339/default.aspx.

Faye, B. (1992). L'élevage et les éleveurs de dromadaires dans la Corne de l'Afrique, in "Relations Homme-animal dans les sociétés pastorales d'hier et d'aujourd'hui". Festival animalier International de Rambouillet. 25-26 sept 1992, Actes du Colloque, 59-72.

Faye, B. (1997). Guide de l'élevage du dromadaire. Sanofi (publ.), Libourne, France, 126.

Faye, B. (1999). Mission d'appui au projet institutionnel de développement de la filière caméline au Niger. Rapport de mission CIRAD-EMVT n 99008, 21. + annexes

Faye, B. (2009). Pauvreté et solidarité chez les peuples pastoraux, in : L'élevage richesse des pauvres, Coll. Update, Duteurtre G and Faye B (coord), QUAE (publ), Versailles, 77-87.

Faye, B., Bengoumi, M., Barkat, A. (2003). Le développement des systèmes camelins laitiers périurbains en Afrique, in: Atelier Intl. sur le lait de chamelle en Afrique. FAO-CIRAD-KARKARA, Niamey (Niger), 5-8/11/03, 115-125.

Faye, B., Brey, F. (2005). Les relations entre chameaux et société: entre marginalisation et idéalisation. Ethnozootech-Varia, 77, 43-50.

Faye, B. (2006). La vache et autres herbivores. Passion et raison africaine. Partenariat OCHA/les cafés GEO, Café Flore, Paris. Accessed 25 April 2006 www.lemangeurocha.com.

Faye, B., Bonnet, P. (2012). Camel sciences and economy in the world: current situation and perspectives. In: Proc. 3rd ISOCARD conf, Keynote presentations, 29th January -1st February 2012, Muscat (Sultanate of Oman), 2-15.

Godard, O. (2010). Cette ambiguë adaptation au changement climatique. Natures Sciences Sociétés, 18, 287-297. 
Hammo, A., Akhmad, M., llou, I. (2003). Organisation de la collecte de lait de chamelle à Agadez, in :Atelier Intl. sur le lait de chamelle en Afrique. FAO-CIRAD-KARKARA, Niamey (Niger), 5-8/11/03, 128-143.

Herrmann, S.M., Anyamba, A., Tucker, C.J. (2005). Recent trends in vegetation dynamics in the African Sahel and their relationship to climate. Global Envir. Change, 15, 394404.

Hulme, M. (2001). Climatic perspectives on Sahelian desiccation.1973-1998. Global Envir. Change, 11, 19-29.

Khalafalla, A.I., Saeed, I.K., Ali, Y.H., El Hassan, A.M., Ali Abu, O., Mohamed, G., Zakia, A. (2005). Morbillivirus infection of camels in eastern sudan. New emerging fatal and contagious disease. In: Proc of the Int. Conf. on Infectious Emerging Disease, Al Ain, UAE, 26th March- April 1, 2005, 126-127.

Khalafalla, A.I., Saeed, I.K., Ali, Y.H., Abdurrahman, M.B., Kwiatek, O., Libeau, G., Obeida, A.A., Abba, Z. (2010). An outbreak of peste des petits ruminants (PPR) in camels in the Sudan. Acta Trop, 116(2), 161-165.

Kassahun, A., Snyman, H.A., Smit, G.N. (2007). Impact of rangeland degradation on the pastoral production systems, livelihoods and perceptions of the Somali pastoralists in Eastern Ethiopia. J Arid Environ, 72, 1265-128.

Kràtli, S. (2007). Cows who choose domestication; generation andmanagement of domestic animal diversity by WoDaaBe pastoralists (Niger), PhD thesisn of Sussex University, 325 p. + annexes.

Lioubimtseva, E., Henebry, G.M. (2009). Climate and environmental change in arid Central Asia: impacts, vulnerability and adaptations. J Arid Environ, 73, 963-977.

Leroux, J. (2004). La dynamique de la grande sécheresse du sahel. In : La dynamique du temps et du climat, 2e édition, DUNOD (publ), 210.

Little, P.D., Mahmoud, H., Coppock, D.L. (2001). When deserts flood: risk management and climatic processes among East African pastoralists. Clim Res, 19, 149-159

Mahé, G., Paturel, J.E. (2009). 1896-2006 Sahelian annual rainfall variability and runoff increase of Sahelian rivers. C.R. Geosci., 341, 538-546.

Marty, A., Eberschweiler, A., Dangbet, Z. (2009). Au cœur de la transhumance. Un campement chamelier au Tchad central. Khartala (publ), Paris (France), 277.

Mohammed, A. (2003). Organisation d'un réseau de collecte de lait en Mauritanie, in : Atelier Int. sur le lait de chamelle en Afrique. FAO-CIRAD-KARKARA, Niamey (Niger), 58/11/03, 104-112.

Mortimore, M.J., Adams, W.M. (2001). Farmer adaptation, change and 'crisis' in the Sahel. Global Envir. Change, 11, 49-57.

Nardone, A., Ronchi, B., Lacetera, N., Ranieri, M.S., Bernabucci, U. (2010). Effects of climate changes on animal production and sustainability of livestock systems. Livest Sci, 130, 57-69.

Nicholson, S.E. (2001). Climatic and environmental change in Africa during the last two centuries. Clim Res, 17, 123-144.

Ngeiywa, K.J. (2012). Advocacy for camel research and development in Kenya. In: Proc. 3rd ISOCARD conf, Keynote presentations, 29th January -1st February 2012, Muscat (Sultanate of Oman), 355.

Olwoch, J.M., Reyers, B., Engelbrecht, A., Erasmus, B.F.N. (2007). Climate change and the tickborne disease: Theileriosis (East Coast fever) in sub-Saharan Africa. J Arid Environ, 72, 108-120.

Ozer, P., Erpicum, M. (1995). Méthodologie pour une meilleure représentation spatiotemporelle des fluctuations pluviométriques observées au Niger depuis 1905. Sécheresse, 6, 103-108. 
Pacholek, X., Vias, G., Faye, B., Faugère, O. (2000). Elevage camelin au Niger: référentiel zootechnique et sanitaire. Publ. Coopération Française, Niamey, Niger, 93.

Potkanski, T. (1999). Mutual assistance among the Ngorongoro Maasai. In : « The poor are not us. Poverty and pastoralism », D. M. Anderson and V. Broch-Due (Eds.), Publ. Eastern African Studies, Oxford, 199-217.

Raynaut, C. (2001). Societies and nature in the Sahel: ecological diversity and social dynamics. Global Envir. Change, 11, 9-18.

Richard, D., Hoste, C., Peyre de Fabregues, B. (1985a). Le dromadaire et son élevage. Coll. Etudes et synthèses. Ed. IEMVT, Maisons-Alfort, 161.

Richard, D., Planchenault, D., Giovanetti, J.F. (1985b). Projet de développement de l'élevage dans le Niger Centre-Est. Production caméline. Rapport final IEMVT, Maisons-Alfort, 125.

Roger, F., Diallo, A., Yigezu, L.M., Hurard, C., Libeau, G., Mebratu, G.Y., Faye, B. (2000). Investigations of a new pathological condition of camels in Ethiopia. $\mathrm{J}$ Camel Pract Res, 7(2), 163-166.

Sirohi, S., Michaelowa, A. (2007). Sufferer and cause: Indian livestock and climatic change. Clim change, 85, 285-298.

Swai, E.S., Moshy, W., Mshanga, D., Lutatina, J., Bwanga, S. (2011). Intestinal parasitic infections of camels in the agro and pastoral areas of northern Tanzania. Vet Res, 4, 4-38.

Tschakert, P. (2007). Views from the vulnerable: understanding climatic and other stressors in the Sahel. Global Envir. Change, 17, 381-396.

Thébaud, B. (1988). Elevage et développement au Niger. Genève. Editions du Bureau International du Travail. I-8 ${ }^{\circ}$ de XIV-147.

Thebaud, B., Batterbury, S. (2001). Sahel pastoralists: opportunism, struggle, conflict and negotiation. A case study from eastern Niger. Global Envir. Change., 11, 69-78.

Thornton, P.K., Van de Steeg, J., Nortenbaert, A., Herrero, M. (2009). The impacts of climate change on livestock and livestock systems in developing countries: A review of what we know and what we need to know. Agric Syst, 101, 113-127

Turner, M.D., Williams, T.O. (2002). Livestock Market Dynamics and Local Vulnerabilities in the Sahel. World. Develop., 30, 683-705.

UNDP. (2009). United Nation Development Programme, Available at http://hdr.undp.org/en/statistics.

Vall, E. (1996). Capacités de travail comportement à l'effort et réponses physiologiques du zébu de l'âne et du cheval au Nord-Cameroun. Thèse de Doctorat ENSAM, Montpellier (France), 418.

Vias, G., Bonfoh, B., Garba, M., Ilou, I., Kamil, H., Faye, B. (2003). Valorisation du lait de chamelle au Sahel : opération "fromages camélins" dans le Tadsit (Niger) et à Tombouctou (Mali), in : Atelier Int. sur le lait de chamelle en Afrique. FAO-CIRADKARKARA, Niamey (Niger), 5-8/11/03, 157-166.

Vias, G., Ibrahim, Y., Vall, E., Faye, B. (2004). La traction caméline un apport important dans l'évolution des pratiques de traction animale au Niger. In: Actes de l'atelier: " traction animale et stratégies d'acteurs: quelle recherche quels services face au désengagement des Etats ? ", 17-21/11 2003, Bobo-Dioulasso, Burkina-Faso. Rev Elev Méd Vét Pays trop, 57, 177-179

Wall, R., Rose, H., Ellse, L., Morgan, E. (2011). Livestock ectoparasites: Integrated management in a changing climate. Vet. Parasitol., 180, 82-89.

Wernery, U., Kaaden, O.R. (2002). Infectious Diseases in Camelids $\left(2^{\text {nd }}\right.$ revised and enlarged edition), Berlin-Vienne (Germany-Austria), Blackwell WissenschaftsVerlag, 404

Wilson, R.T. (1984). The camel. London, Longman (Publ), 223. 
Wilson, R.T. (1989). Ecophysiology of the camelidae and desert ruminants. Ed. SpringerVerlag, New-York (USA), 120

Yagil, R. (1985). The desert camel: comparative physiological adaptation. Ed. Karger, Basel (Switzerland), 163.

Zika, M., 2012. Evaluation et gestion des risques climatiques sur le système agropastoral: cas des communes de Say et de Tamou. Master report, Université Abdou Moumouni, Niamey (Niger), 70

(C) 2012 Faye et al.; This is an Open Access article distributed under the terms of the Creative Commons Attribution License (http://creativecommons.org/licenses/by/3.0), which permits unrestricted use, distribution, and reproduction in any medium, provided the origin al work is properly cited. 